\title{
Safety in medical simulation-overlooked or underappreciated?
}

\author{
Alan F. Merry, MBChB • Daniel W. Wheeler, DM, PhD
}

Published online: 8 July 2011

(C) Canadian Anesthesiologists' Society 2011

In the past, many doctors learned their craft in understaffed settings with heavy patient loads. Long hours of work with considerable responsibility provided the opportunity to gain experience and build skills rapidly. ${ }^{1}$ Patients accepted junior doctors in no small part because of a lack of alternatives. Altered perceptions about what is reasonable in relation to hours of work, the role of trainee doctors, and the expectations of patients have changed the situation considerably. The airline industry (amongst others) has created high public expectations for safe and reliable services, and these expectations are extending increasingly to healthcare.

One notable difference between the airlines and hospitals lies in the way individuals are trained. In medicine, trainee doctors are still relied on to contribute towards much of the day-to-day workload. In many countries, trainee doctors still undertake a large portion of the service work, often with only distant supervision, particularly at night. Whether this experience is learning or training is a moot point. By contrast, passengers expect fully trained pilots. Increasingly, patients expect their doctors to be adequately trained, and they also expect their doctors to maintain their expertise and skill throughout their careers. One way to meet these expectations is through simulation. ${ }^{2-4}$

\footnotetext{
A. F. Merry, MBChB ( $\square)$

Department of Anaesthesiology, University of Auckland, Private Bag 92019, Auckland 1142, New Zealand

e-mail: a.merry@auckland.ac.nz
}

\author{
A. F. Merry, MBChB \\ Department of Anaesthesia, Auckland City Hospital, Auckland, \\ New Zealand \\ D. W. Wheeler, DM, PhD \\ Division of Anaesthesia, University of Cambridge, \\ Addenbrooke's Hospital, Cambridge, UK
}

Today, simulation is integral to pilot training, credentialing, and maintaining competence. Anesthesiologists have adopted simulation to facilitate various aspects of their training, and they have made great advances in developing realistic simulators and acquiring expertise in this form of education. In principle, it is believed that simulation provides a safe and controlled environment in which experience can be provided exactly as and when required, and reflective learning can be facilitated through skilled debriefing. ${ }^{5}$

Simulation in anesthesia is not as well developed as simulation in the aviation industry, and levels of realism in the former fall far short of those taken for granted in the latter. However, progress is being made, and staff members at many simulation centres take pride in ensuring that the experience of participation in their simulated scenarios is as close to clinical practice as possible. One way to achieve this is to incorporate standard anesthetic equipment into their simulations (e.g., anesthetic machines, monitors, defibrillators, infusion pumps, drugs, labels, and electronic or manual charts) that participants use in their daily practice.

In the current issue of the Journal, Riem, Boet, and Chandra report a case in which this approach created a risk for staff and students in their simulation centre. ${ }^{6}$ It seems that an unregulated flow of carbon dioxide, which was "exhaled" from a Laerdal SimMan ${ }^{\circledR} 3 \mathrm{G}$ (Laerdal, Stavanger, Norway) patient simulator, caused a precipitous increase in the temperature of soda lime being used during a simulated case. The authors raise the possibility that simulation may become "too realistic" and call for greater awareness of the potential risks associated with taking equipment into environments for which it was not intended (many simulations are carried out in modified offices rather than properly constituted operating rooms or ward areas). They emphasize the importance of including safety in standards for accrediting simulation centres. 
These are important messages, and for many, this case report may be a timely reminder that simulation, like many other worthwhile activities, requires a certain level of knowledge, care, and skill to be both safe and effective. At the same time, we should not forget that the primary aim of this type of training is to prepare anesthesiologists to provide safe anesthesia to live patients in clinical settings using equipment and drugs that do carry certain hazards.

Equipment and medications are sometimes modified for use in simulations to enhance safety, reduce cost, or increase convenience; examples include so-called "Hollywood defibrillators" that do not deliver real shocks, and labelled syringes that contain water instead of drugs. ${ }^{6}$ Riem, Boet, and Chandra make the point that many centres choose not to use real gases and vapours, but instead simply generate relevant readings on proprietary monitors to provide the required cues to participants. However, this is the catch; if real equipment and drugs are not used, the lessons learned may not always translate accurately into the clinical environment. Indeed, such training could breed a degree of complacency in students that would increase the risk they faced when confronted with the real thing. It will not serve either these practitioners or their patients well if training fails to instil an awareness of the risks inherent in their work and the capability to handle equipment and medications safely. Ironically, the case reported by these authors occurred in part because of compromises in realism inherent in the design of their simulator, i.e., the carbon dioxide levels "exhaled" by the simulator were not being monitored as they would have been in a live patient, or even (as they explain) as they would have been with certain other simulators, such as the METI HPS $®$ (METI, Sarasota, FL, USA).

The question as to how real a simulation ought to be has been discussed in depth, notably in a recent article by Dieckmann, Gaba, and Rall ${ }^{7}$ (see also commentary by Rudolph, Simon, and Raemar). ${ }^{8}$ Using the work of social psychologist, Uwe Laucken, ${ }^{9}$ they propose a theoretical framework for considering realism in simulation based on three modes of thinking, i.e., physical, semantic, and phenomenal. The physical mode concerns the materials used in a simulation, such as the mannequin and anesthetic equipment, and it is compromised, to a certain extent, by the limitations of the components used. For example, it would be difficult to mistake a mannequin for a human; defibrillators are often disarmed for safety; and providing real opioids in syringes poses several practical difficulties. In medical simulation, realism depends on concepts and their relationships; for example, a certain dose of a vasopressor will cause a predictable increase in blood pressure, and semantic realism will be achieved if the simulated response fits with the participants' experiences and expectations. Achieving semantic realism is compatible with replacing drugs with saline. Phenomenal realism is achieved by precisely reproducing the emotions and beliefs the participants would experience in the clinical setting, and thereby providing an immersive experience which may be expected to provide learning that will translate into clinical practice. Dieckmann et al. make a widely held point when they state, "In many cases, it is more cost effective to establish strong semantic and phenomenal frameworks of the scenario that help participants interpret information and enact their roles, rather than merely trying to maximize the physical fidelity". 7

There is no doubt that weaving the spell that immerses participants in the experience of simulation and creates a strong illusion of reality does require attention to all three aspects of fidelity. The equipment error described by Riem et al. as having caused the incident illustrates not only that simulation is not risk-free but also that the occurrence of the equipment error would have spectacularly broken the spell for the participant(s). In fact, this sense of realism is very fragile and can be destroyed easily through failure of any of the three dimensions discussed above. Often, limitations in physical realism can be managed, but this requires close attention to the semantic expectations of the participants. This was illustrated (unintentionally) in a demonstration at a major anesthesia conference some years ago. The title of the scenario advertised in the program included the words "human error". During the scenario, ventricular fibrillation (VF) occurred with a somewhat fine VF trace in a simulated patient undergoing anesthesia. The participants instituted appropriate therapy, including cardiac massage and repeated attempts to defibrillate the heart. However, the capnograph trace continued to show cyclical variation in expired carbon dioxide levels that did not appear to be compatible with the reduced cardiac output that might be expected in this scenario. One audience member (A.F.M.) reached a twofold conclusion; the simulation was about the possibility that an abnormal electrocardiographic trace could reflect poorly connected leads and electrical interference rather than VF, and it was also about the importance of integrating all diagnostic clues into one's assessment of any situation. In no small part, this conclusion was reached because the title of the session suggested that some element of human error would be involved in the scenario. In the group debriefing that ensued, this interpretation was incorrect - the scenario was really about $\mathrm{VF}$, and the capnographic trace was attributable to the (arguably imperfect) physical modelling or scripting underlying the simulation. The element of "human error" allegedly integrated into the objectives of the session was, to say the least, obscure. At one level, we can only be sympathetic with the instructors - the simulation community is still struggling with very inadequate models, even in our most sophisticated simulators. However, for participants, this gap between a common understanding of the physiology of VF arrest and the 
semantic fidelity of the simulation was discombobulating. The result was that the primary frame of at least one member of the audience was not aligned with that of the instructors. ${ }^{6}$ One could argue that valuable learning was still possible through debriefing and reflection. Alternatively, one could argue that this semantic dissonance was a source of irritation and frustration which impeded learning and discouraged participation in future simulations.

In analyzing this story, the contribution of the session's title, including the words "human error", is relevant. It is true that much can be done to manage the limitations of simulators through the settings in which they are used and through the messages conveyed by other means, including briefing. For example, before starting simulation training sessions, our groups routinely emphasize the limitations of our simulators in reflecting changes in the colour of skin or mucous membranes. We make our approach to dealing with this and other less than ideal aspects of the scenarios explicit through a "fiction contract". ${ }^{6}$ We explain that actors within the simulation (e.g., the nurse or the surgeon) will comment on attributes such as skin colour when appropriate, either to respond to questions or spontaneously to provide guidance to the participant, and these comments can be relied on and taken at face value. In our experience, most participants are able to accommodate this method of managing semantic fidelity in the face of poor physical fidelity. After all, a similar thing might happen when caring for a patient, either because the clinician had been slow to notice a change or because a change was relatively subtle and a second opinion was required to confirm whether or not all was well. We seldom, if ever, use the so-called "voice of God" - comments made over the loudspeaker for similar ends. In our experience, this feels very unrealistic and has considerable potential to shift the experience of participation too far from the sense of being in a clinical setting with a live patient and in a real crisis to that of role-playing.

Of course, all people make errors, including simulation instructors and simulator operators. Furthermore, truth is often illusive. Finding a reliable source of information on capnography is more difficult than one might imagine during a cardiac arrest in a ventilated patient while cardiac massage is being performed to varying degrees of effectiveness. In the above story, the observer may have been wrong and the fidelity may have been accurate in this regard. The issue, however, is the need for a shared mental model, ideally during the scenario but at least during the debriefing (in general, the case to be debriefed should be primarily the one experienced by the participant rather than the one intended by the instructor). Furthermore, instructors often have as much to learn during simulations as the participants, particularly when the latter are senior clinicians. A paradigm wherein the emphasis is on peer learning and the main role of the instructors is to facilitate and focus the discussion has much merit in these settings. Nevertheless, as Dieckmann, Gaba, and Rall state, “...one might assume that the willing suspension of disbelief is easier, if the inconsistencies within the scenario are not due to operator mistakes but have logical reason within the scenario." ${ }^{\text {It }}$ seems to us that high levels of physical fidelity can only be helpful in the context of simulation. As illustrated in our story, the social influences are at least equally important. On the one hand, these can often offset physical limitations, and on the other hand, physical perfection cannot compensate for deficiencies in the social elements of a simulation. However, acknowledging the shortcomings in the physical fidelity of current simulators and emphasizing the importance of semantic and phenomenal fidelity is quite different from declaring that physical fidelity does not matter.

Ideally, strong competition will drive progress towards simulators with comprehensive and validated physiological models capable of functioning autonomously and will call for more life-like mannequins that will interact spontaneously to real medications, gases, vapours, fluids, defibrillators, and so forth. At present, it is difficult to discern such competition, possibly because the market for relatively simple simulators used to teach life support is larger than that for sophisticated simulators used in immersion simulations of complex anesthesia scenarios. As customers, anesthesiologists currently have no choice but to find ways of working around the limitations of existing simulators. It would be too easy to reframe this reality so as to suggest that these compromises are a virtue and pursuit of too much fidelity is counterproductive. Given the technological limitations and imperfections of even the most sophisticated simulators currently available, we recognize that it is incumbent upon staff to find ways of ensuring that scenarios are worthwhile and that simulation is effective. At the same time, though, we should not reduce pressure on manufacturers to improve the realism of their products.

In our view, the best way to practice the craft of anesthesia is by using the drugs, gases, vapours, and devices used in daily clinical practice. In simulation, this implies using a facility that meets the safety standards of an operating room, including scavenging, compliance with electrical codes, tracking and security of drugs, replenishment of carbon dioxide, and use of real monitors. It is not necessary for all simulation centres to pursue this level of fidelity or for this level of fidelity to be used in all simulations, even in centres where it is provided when required. However, some centres should pursue this level of fidelity for some simulations, particularly for those used in high stakes assessments or in research into means of improving patient safety. ${ }^{10-12}$ Whatever the level of fidelity selected for any particular centre, the safety of those who use the centre is of utmost importance. Riem et al. have made a useful contribution in reminding us of this important aspect of simulation. 


\section{La sécurité en simulation médicale-une composante négligée ou sous-estimée?}

Par le passé, nombre de médecins ont appris leur art dans des environnements où le personnel était insuffisant et les patients extrêmement nombreux. Les longues heures de travail allaient de pair avec une responsabilité considérable, ce qui leur permettait d'acquérir de l'expérience et des compétences rapidement. ${ }^{1}$ Les patients acceptaient d'être traités par de jeunes médecins - principalement parce qu'ils n'avaient pas réellement le choix. L'évolution de ce que l'on considère comme raisonnable en termes d'heures de travail, du rôle des médecins en formation et des attentes des patients, tous ces éléments ont substantiellement changé la donne. Le secteur de l'aviation, entre autres, a créé des attentes élevées du public en matière de services à la fois sécuritaires et fiables, et ces attentes occupent une place de plus en plus importante dans les soins de santé.

On remarque une différence entre l'aviation et les hôpitaux dans la façon de former les gens. En médecine, on compte sur les médecins en formation pour qu'ils endossent une grande partie de la charge de travail quotidienne. Dans de nombreux pays, les médecins en formation ont encore la charge d'une importante portion du travail accompli dans un service, et ne bénéficient souvent que d'une supervision distante, particulièrement pendant la nuit. S'agit-il là d'apprentissage ou de formation? La controverse demeure. En revanche, les passagers d'un avion s'attendent à avoir des pilotes ayant terminé avec succès leur formation. On observe que les patients s'attendent de plus en plus à ce que leurs médecins soient formés de façon adéquate, et ils s'attendent également à ce que leurs médecins maintiennent leur expertise et leurs compétences tout au long de leur carrière. La simulation est l'une des façons de répondre à ces attentes. ${ }^{2-4}$

Aujourd'hui, la simulation fait partie intégrante de la formation, de l'obtention des diplômes et du maintien de la compétence des pilotes. Les anesthésiologistes ont adopté la simulation afin de faciliter divers aspects de leur formation, et ils ont accompli d'importants progrès dans la mise au point de simulateurs réalistes. En outre, ils ont acquis une certaine expertise dans cette forme d'éducation. En principe, on pense que la simulation offre un environnement sécuritaire et contrôlé dans lequel on peut acquérir une expérience de la façon et au moment voulus, et que l'apprentissage réfléchi peut être facilité par une séance de débriefing bien menée. ${ }^{5}$

La simulation en anesthésie n'est pas aussi bien développée que la simulation dans le monde de l'aviation, et les niveaux de réalisme de la première sont bien loin de ceux pris pour acquis dans le second. Toutefois, les progrès sont bien là, et les membres du personnel de nombreux centres de simulation s'enorgueillissent d'assurer que l'expérience de participation dans certains scénarios simulés est aussi proche que possible de la pratique clinique. L'une des façons d'atteindre ce but est d'intégrer des équipements d'anesthésie standard (par ex. appareils d'anesthésie, moniteurs, défibrillateurs, pompes à perfusion, médicaments, étiquettes, et dossiers électroniques ou manuels) que les participants utilisent dans leur pratique de tous les jours.

Dans ce numéro du Journal, Riem, Boet et Chandra rapportent un cas dans lequel une telle approche a mis en danger le personnel et les étudiants dans leur centre de simulation. ${ }^{6}$ Il semble qu'un débit non réglé de monoxyde de carbone, «expiré » par un simulateur de patient Laerdal SimMan ${ }^{\circledR} 3 \mathrm{G}$ (Laerdal, Stavanger, Norvège), ait provoqué une augmentation subite de la température de la chaux sodée utilisée dans le cas simulé. Selon les auteurs, la simulation peut potentiellement devenir « trop réaliste »; par conséquent, ils appellent à une vigilance accrue face aux risques potentiels associés à l'installation de matériel dans des environnements non conçus à cet effet (de nombreuses simulations sont réalisées dans des bureaux modifiés plutôt que dans des salles d'opération ou salles d'hôpital reconstituées avec fidélité). Ils soulignent aussi l'importance de l'inclusion de mesures de sécurité dans les normes d'accréditation des centres de simulation.

Ces messages sont importants et, pour de nombreuses personnes, cet article et le cas décrit sont un rappel opportun que la simulation, tout comme nombre d'autres activités louables, requiert un certain niveau de connaissances, de prudence et de compétences afin d'être à la fois sécuritaire et efficace. Cela étant dit, gardons tout de même à l'esprit que le but premier de ce type de formation est de préparer les anesthésiologistes à fournir une anesthésie sécuritaire à des patients bien vivants dans des contextes cliniques en se servant d'appareils et de médicaments qui comportent certains risques.

Le matériel et les médicaments sont parfois modifiés avant d'être utilisés dans une simulation afin d'en améliorer la sécurité, de réduire les coûts ou à des fins pratiques; par exemple, il existe des "défibrillateurs hollywoodiens », qui ne fournissent pas de choc réels, ou des seringues étiquetées contenant de l'eau au lieu de médicaments. ${ }^{6}$ Riem, Boet et Chandra remarquent que de nombreux centres n'utilisent pas de gaz ou d'halogénés réels, mais génèrent plutôt les données pertinentes sur des moniteurs spéciaux, ce qui permet aux participants d'obtenir les données nécessaires à la réalisation de la simulation. Mais c'est là que réside le piège: si l'on n'utilise pas les appareils et médicaments réels, les leçons apprises pourraient ne pas 
se traduire précisément dans un environnement clinique. En effet, une telle formation pourrait favoriser une certaine complaisance chez les étudiants, ce qui augmenterait les risques encourus une fois confrontés à la réalité. Si la formation ne parvient pas à instiller une conscience des risques inhérents à leur travail et à leur donner la capacité de gérer du matériel et des médicaments de façon sécuritaire, cela ne sera pas de grand service à ces praticiens - ni à leurs patients. Ironie du sort, le cas rapporté par ces auteurs est survenu en partie en raison de compromis faits au niveau du réalisme et inhérents à la conception de leur simulateur. En effet, les niveaux de dioxyde de carbone « expirés » par le simulateur n'étaient pas surveillés comme ils l'auraient été chez un vrai patient, ou même (comme les auteurs l'expliquent) comme ils l'auraient été avec d' autres simulateurs, comme le METI HPS $®$ (METI, Sarasota, FL, É.-U.).

La question de savoir à quel niveau de réalisme une simulation doit aspirer a été amplement discutée, notamment dans un article récent de Dieckmann, Gaba et Rall $^{7}$ (voir aussi le commentaire de Rudolph, Simon et Raemar). ${ }^{8}$ En se fondant sur les travaux d'Uwe Laucken, ${ }^{9}$ un psychologue social, ils proposent un cadre théorique qui permet d'examiner le réalisme d'une simulation donnée selon trois modes de pensée: physique, sémantique, et phénoménal. Le mode physique touche aux matériels utilisés dans une simulation, comme le mannequin et les appareils d'anesthésie, et il est compromis, dans une certaine mesure, par les limites inhérentes aux composantes utilisées. Par exemple, il serait difficile de prendre un mannequin pour un être humain; les défibrillateurs sont souvent désarmés par mesure de sécurité; et l'administration d'opioïdes réels dans des seringues pose plusieurs difficultés pratiques. Dans la simulation médicale, le réalisme dépend de concepts et des relations qu'ils entretiennent; par exemple, une dose $\mathrm{X}$ d'un vasopresseur Y provoquera une augmentation prévisible de la tension artérielle; le réalisme sémantique sera atteint si la réponse simulée correspond aux expériences et aux attentes des participants. En outre, le remplacement de médicaments par une solution salée ne nuit pas à l'obtention d'un réalisme sémantique. On obtient un réalisme phénoménal en reproduisant précisément les émotions et les principes que les participants auraient dans un contexte clinique, fournissant ainsi une expérience immersive qui peut procurer un apprentissage qui se traduira dans la pratique clinique. Dieckmann et coll. abondent dans le sens de plusieurs autres quand ils déclarent que « dans de nombreux cas, il est plus rentable d'établir des schémas sémantiques et phénoménaux forts dans un scénario, schémas qui aident les participants à interpréter des informations et jouer leurs rôles, que de simplement essayer de maximiser la fidélité physique [d'un scénario] $»^{7}$

Il ne fait aucun doute que les trois aspects de la fidélité sont nécessaires afin de créer la trame de l'histoire qui permettra d'immerger les participants dans l'expérience de la simulation et de créer une illusion puissante de réalité. L'erreur de matériel que Riem et coll. décrivent comme cause de l'incident illustre non seulement le fait que la simulation n'est pas sans risque, mais également que la survenue de l'erreur de matériel aurait brisé le charme de façon spectaculaire pour le(s) participant(s). En fait, le sens du réalisme est très fragile et peut être facilement détruit si l'une des trois dimensions énumérées plus haut n'est pas à la hauteur. Les limites au niveau du réalisme physique peuvent souvent être gérées, mais pour ce faire, il faut porter une attention particulière aux attentes sémantiques des participants. Une présentation organisée dans le cadre d'un important congrès d'anesthésie il y a quelques années est un bon exemple (certes involontaire). Le titre de la présentation dans le programme comprenait les mots «erreur humaine ». Pendant la présentation, une fibrillation ventriculaire (FV) est survenue avec un tracé un peu fin de FV chez un patient simulé subissant une anesthésie. Les participants ont mis en place un traitement adéquat, y compris un massage cardiaque et des tentatives répétées de défibrillation du cœur. Cependant, le tracé du capnographe a continué de montrer une variation cyclique des niveaux de dioxyde de carbone expiré, ce qui ne semblait pas compatible avec le débit cardiaque réduit attendu dans ce cas. Un membre du public (A.F.M.) est parvenu à une double conclusion: la simulation portait sur la possibilité qu'un tracé électrocardiographique anormal puisse refléter des fils mal raccordés et une interférence électrique plutôt qu'une FV, soulignant également l'importance d'intégrer toutes les pistes diagnostiques lors de l'évaluation d'une situation donnée. Cette conclusion a été atteinte en grande partie parce que le titre de la séance suggérait qu'une part d'erreur humaine serait présente dans le cas présenté. Dans le débriefing de groupe qui s'ensuivit, cette interprétation a été considérée comme incorrecte - le scénario portait véritablement sur la FV, et le tracé capnographique était attribuable au modèle physique et au script (sans doute imparfait) sous-jacent à la simulation. La part « d'erreur humaine » prétendument intégrée dans les objectifs de la séance était néanmoins pour le moins obscure. D'une part, on peut ressentir que de la sympathie pour les instructeurs - les experts en simulation travaillent encore aujourd'hui avec des modèles mal adaptés, même lorsqu'il s'agit de nos simulateurs les plus perfectionnés. Cependant, pour les participants, le fossé entre une compréhension commune de la physiologie de l'arrêt de la FV et la fidélité sémantique de la simulation était déconcertant. Ce fossé a eu pour résultat que le cadre primaire de compréhension d'au moins un membre du public ne concordait pas avec celui des instructeurs. ${ }^{6}$ On pourrait prétendre qu'un enseignement utile était tout de même possible via le débriefing et la réflexion. En 
revanche, on pourrait aussi prétendre que la discordance sémantique a été une source d'irritation et de frustration qui a entravé l'apprentissage et découragé la participation à des simulations futures.

En analysant cette histoire, la contribution du titre de la séance, qui comprenait les mots «erreur humaine », est pertinente. Il va sans dire que beaucoup de choses peuvent être faites pour gérer les limites des simulateurs en travaillant sur les contextes dans lesquels ils sont utilisés et les messages transmis par d'autres moyens, y compris les séances d'information. Par exemple, avant de commencer des séances de formation en simulation, nos groupes soulignent fréquemment les limites de nos simulateurs en ce qui touche à l'imitation des modifications dans la couleur de la peau ou des membranes muqueuses. Notre approche pour gérer cet aspect et d'autres aspects qui laissent à désirer des cas simulés consiste à établir un «contrat de fiction ». ${ }^{6}$ Nous expliquons aux participants que les acteurs au sein de la simulation (par ex. l'infirmière ou le chirurgien) feront des commentaires sur des attributs tels que la couleur de peau lorsque cela est indiqué, soit en réponse à des questions ou de façon spontanée afin de guider le participant, et que ces commentaires sont fiables et peuvent être pris au pied de la lettre. Dans notre expérience, la plupart des participants sont capables de s'adapter à cette façon de gérer la fidélité sémantique et ce, même lorsque la fidélité physique laisse à désirer. Après tout, une situation semblable peut survenir lorsqu' on prend soin d'un patient, soit parce que le clinicien a mis du temps avant de remarquer un changement ou parce qu'un changement était relativement subtil et qu'une deuxième opinion était nécessaire pour confirmer que tout allait bien ou non. Il arrive rarement, voire jamais, que nous ayons recours à la «voix de Dieu », c'est-à-dire à des commentaires transmis via un haut-parleur, pour arriver à des fins semblables. Notre expérience nous a appris que cela semblait très peu réaliste et pouvait potentiellement déplacer l'expérience de participation trop loin du sentiment de présence dans un contexte clinique avec un patient réel et dans une crise réelle, dans un contexte de jeu de rôle.

Bien entendu, nous faisons tous des erreurs, y compris les instructeurs de simulation et les opérateurs de simulateurs. En outre, la vérité est souvent trompeuse. Il est plus difficile de trouver une source fiable d'informations sur la capnographie qu'on pourrait penser pendant l'arrêt cardiaque d'un patient ventilé et qu'un massage cardiaque plus ou moins efficace est en cours. Dans l'histoire relatée ci-dessus, l'observateur pourrait s'être trompé et la fidélité pourrait avoir été précise à cet égard. Le problème toutefois porte sur le besoin d'un modèle mental partagé, idéalement pendant le cas mais au moins pendant le débriefing (en général, le cas à débriefer doit être avant tout celui vécu par le participant plutôt que celui prévu par l'instructeur). De plus, les instructeurs ont souvent autant à apprendre pendant les simulations que les participants, particulièrement lorsque ces derniers sont des cliniciens aguerris. Dans de tels contextes, il est très utile d'établir un paradigme où l'importance va à l'apprentissage par les pairs et où le rôle principal des instructeurs est de faciliter et de diriger la discussion. Néanmoins, comme Dieckmann, Gaba et Rall le déclarent, " on pourrait prendre pour acquis que la suspension volontaire de l'incrédulité est plus facile si les incohérences du cas ne sont pas dues aux erreurs de l'opérateur mais ont une raison logique dans le scénario présenté. ${ }^{7} \mathrm{Il}$ nous semble que des niveaux élevés de fidélité physique ne peuvent être utiles que dans un contexte de simulation. Comme l'illustre notre histoire, les influences sociales sont au moins aussi importantes. D'une part, celles-ci peuvent souvent compenser des limites physiques; d'autre part, la perfection physique ne peut compenser les défauts des éléments sociaux d'une simulation. Cependant, tout en reconnaissant que la fidélité physique des simulateurs actuels comporte des défauts et en soulignant l'importance de la fidélité sémantique et phénoménale, il ne faut pas minimiser l'importance de la fidélité physique.

Idéalement, une concurrence acharnée au sein de l'industrie entraînera des progrès vers la mise au point de simulateurs munis de modèles physiologiques complets et validés capables de fonctionner de façon autonome, ce qui encouragera la création de mannequins plus réalistes qui interagiront spontanément avec les médicaments réels, les gaz, les halogénés, les liquides, les défibrillateurs, etc. À l'heure actuelle, une telle concurrence n'est pas évidente, possiblement parce que le marché des simulateurs relativement simples qui permettent d'enseigner le maintien des fonctions vitales est plus important que le marché pour des simulateurs plus perfectionnés utilisés dans les simulations d'immersion dans des cas d'anesthésie complexes. En tant que clients, les anesthésiologistes n'ont pour le moment pas le choix: ils doivent trouver des façons de travailler avec les limites des simulateurs existants. Il serait trop facile de recadrer cette réalité de façon à suggérer que ces compromis sont une vertu et que la poursuite d'une fidélité trop 'fiable' est contre-productive. Étant donné les limites technologiques et les imperfections des simulateurs actuellement disponibles - même les plus perfectionnés -, nous sommes conscients qu'il incombe au personnel des centres de simulation de trouver des façons de garantir que les scénarios présentés en valent la peine et que la simulation est efficace. Cependant, nous ne devons pas relâcher la pression sur les fabricants afin qu'ils améliorent le réalisme de leurs produits.

Selon nous, la meilleure façon de pratiquer l'art de l'anesthésie est d'utiliser les médicaments, les gaz, les halogénés et les appareils utilisés dans la pratique clinique quotidienne. En simulation, cela implique d'utiliser un 
endroit qui réponde aux normes de sécurité d'une salle d'opération, y compris au niveau de la récupération d'air, de la conformité des codes électriques, de la traçabilité et de l'innocuité des médicaments, du remplissage du dioxyde de carbone et de l'utilisation de moniteurs réels. Il n'est pas nécessaire que tous les centres de simulation aspirent à un tel niveau de fidélité ou qu'un tel niveau de fidélité soit utilisé dans toutes les simulations et ce, même dans les centres où elle est disponible lorsque nécessaire. Cependant, certains centres devraient aspirer à ce niveau de fidélité dans certaines simulations, particulièrement dans celles qu'on utilise dans des évaluations à enjeux importants ou dans la recherche visant à trouver des moyens d'améliorer la sécurité des patients. ${ }^{10-12}$ Quel que soit le niveau de fidélité choisi dans un centre donné, la sécurité des utilisateurs de ce centre est capitale. La contribution de Riem et coll. est utile pour nous rappeler cet élément crucial de la simulation.

Competing interests A.F. Merry is responsible for a simulation facility at the University of Auckland. D.W. Wheeler conducts patient safety research in the simulation centre in Cambridge University Hospital's NHS Foundation Trust.

\section{References}

1. Merry AF. To do or not to do?-How people make decisions. J Extra Corpor Technol 2011; 43: P39-43.
2. Gaba DM, DeAnda A. A comprehensive anesthesia simulation environment: re-creating the operating room for research and training. Anesthesiology 1988; 69: 387-94.

3. Gaba DM. The future vision of simulation in healthcare. Simul Healthc 2007; 2: 126-35.

4. Wheeler DW, Williams CE, Merry AF. Pulling the plug on ad hoc critical incident training. Br J Anaesth 2009; 103: 145-7.

5. Cumin D, Weller JM, Henderson K, Merry AF. Standards for simulation in anaesthesia: creating confidence in the tools. Br J Anaesth 2010; 105: 45-51.

6. Riem N, Boet $S$, Chandra D. Setting standards for simulation in anesthesia: the role of safety criteria in accreditation standards. Can J Anesth 2011; 58. doi:10.1007/s12630-011-9541-3.

7. Dieckmann P, Gaba D, Rall M. Deepening the theoretical foundations of patient simulation as social practice. Simul Healthc 2007; 2: 183-93.

8. Rudolph JW, Simon R, Raemer DB. Which reality matters? Questions on the path to high engagement in healthcare simulation. Simul Healthc 2007; 2: 161-3.

9. Laucken U. [Theoretical Psychology]. Oldenburg, Germany: Bibliotheks-und Informationssystem der Universität; 2003.

10. Merry AF, Weller JM, Robinson BJ, et al. A simulation design for research evaluating safety innovations in anaesthesia. Anaesthesia 2008; 63: 1349-57.

11. Wheeler DW, Degnan BA, Murray LJ, et al. Retention of drug administration skills after intensive teaching. Anaesthesia 2008; 63: 379-84.

12. Wheeler DW, Carter JJ, Murray LJ, et al. The effect of drug concentration expression on epinephrine dosing errors: a randomized trial. Ann Intern Med 2008; 148: 11-4. 